\title{
Facing Cilegon 2025 Water Crisis
}

\author{
Adipati Rahmat Gumelar ${ }^{1}$, Dwita Sutjiningsih ${ }^{2}$, Abimanyu Takdir Alamsyah $^{3}$, \\ Setyo Sarwanto Moersidik ${ }^{4}$ \\ \{adipatirahmat@gmail.com¹, dwita@eng.ui.ac.id², takdir65@gmail.com³
}

\begin{abstract}
School of Environmental Sciences, Universitas Indonesia, Indonesia ${ }^{1}$, Faculty of Engineering, Universitas Indonesia, Depok, West $\mathrm{Java}^{2}$, Faculty of Engineering, Universitas Indonesia, Indonesia ${ }^{3}$
\end{abstract}

\begin{abstract}
This paper addresses the challenges in discussing renewal of clean water in the city of Cilegon in 2025. The predictions submitted by the Ministry of National Development Planning and also the Ministry of Public Works and Public Housing, reminded about the possibility of a deficit in water resources in the city of Cilegon, then for the City of Cilegon it will no longer be fulfilled. The water crisis which is expected to have an impact on industrial decline and a decline in the level of society must be avoided as far as possible. This research uses a dynamic system method that is able to model the water movement of the City of Cilegon, to then build a scenario of anticipation of the water crisis in 2025. This study discusses how to arrange the water planning of the City of Cilegon which can be used by using water resources in the City of Cilegon independently and sustainably. These findings are expected to contribute to building an agreed city water resources governance scenario to support the improvement of future crises. This study discusses why removing water in the City of Cilegon, the Government of the City of Cilegon needs to improve its water using new water sources, namely from sea water and rain water, and helps support groundwater that has been changed in price.
\end{abstract}

Keywords: Water crisis, Cilegon, System Dynamics, Coastal City.

\section{Introduction}

Water is a limited natural resource (FAO, 2018), so its utilization must be done wisely (UN, 1993). As a tropical country, Indonesia has a fairly high average rainfall (more than $2,000 \mathrm{~mm}$ per year) and abundant water resources (BPS, 2018). However, the results of a study by the Ministry of Public Works in 2005 and also BAPPENAS in 1997, precisely predicted that at least in 2025, Indonesia would experience a clean water crisis.

A coastal city is a city that consists of five main functions, namely settlements, cities, industry, tourism and conservation (KKP, 2008). These functions interact with each other as an environmental system that requires a large amount of water resources. In cities located in coastal areas, the clean water crisis will be more severe because the presence of these cities on the seashore will double the need for water and also water resources under pressure from the influence of climate and sea water intrusion (PRPW, 2015).

The city of Cilegon in Banten Province, is a large city on the western tip of Java. Its very strategic position because it is dealing directly with the island of Sumatra and traversed by the Indonesian Archipelago Sea Lane 1, makes it one of the centers of industrial activity in Indonesia with an industry growth rate of $14 \%$. The high rate of growth of the industry not only 
has a direct impact on the increasing number of water needs in the City of Cilegon, but also on the need for water for other functions. The function of settlements, urban areas and tourism also increased directly because the increase in the pace of industry also encouraged population growth, increased demand for rapid urban services (trade, education, health, etc.), and required the support of tourist areas as a means of recreation.

The interaction between these functions ultimately leads to the high number of water needs in the city of Cilegon. Whereas, as reported by Suci (2010), water crisis has occurred in most of the Sub-districts in the City of Cilegon and every year shows symptoms that are increasingly widespread (Rakhmawati, 2015).

The city of Cilegon currently relies on the Cidanau River which is the main water source for the Krenceng Reservoir to meet all the water needs of the City of Cilegon (Sugiarto, 2006). However, the Cilegon Mandiri PDAM as the provider of water needs for the City of Cilegon, said that as a result of efforts to expand the activities of a number of industries, the current availability of water is inadequate (Kabar Banten, 2019). This should be a serious concern, because the function of industry is a major supporter of economic activity in the city of Cilegon. A decline in industrial function due to lack of water can directly affect the economy of Cilegon City and the welfare of its people. In addition, as a result of the lack of water availability, the Cilegon Mandiri PDAM has also become unable to meet the demand for cooperation to fulfill the installation of clean water with new housing in the City of Cilegon, because the availability of clean water has indeed been very limited.

The imbalance between water availability and water needs in the city of Cilegon can be illustrated in a water resource balance sheet in the city of Cilegon. However, with the condition of the availability of water resources that are very limited, driven by the necessity to meet the needs of industries that have very high industrial growth rates and also the obligation to serve the water needs of the people of Cilegon City, it is a picture that the condition of the water resources balance in Cilegon City is very likely water crisis conditions as predicted by the Ministry of PUPR and BAPPENAS will occur in 2025. Such conditions are developed as a question in this research, namely how to avoid the water crisis conditions in Cilegon City in 2025 , but still able to meet water needs for the community and also the industry.

\section{Research Methods}

This research is basically an effort to understand ways to be able to meet the water needs of a coastal city in Indonesia to be sustainable. To produce these outcomes, researchers conduct research with a quantitative approach, because this research will be based on field studies, secondary data analyzes, in-depth interviews with stakeholders, and measurable variable analysis; so that researchers are not biased in the implementation of theoretical testing of the situation on the ground, as well as to develop models and develop strategies needed.

In this study, the method used is the system dynamics analysis method to produce output in the form of a simulation of water resource balance in the City of Cilegon. The built water resource balance system will be based on a discount ratio or the next door, with water needs as assets and water availability as liabilities. The water demand sub-system will consist of five sub-system functions of coastal cities, namely settlements, cities, industries, tourism and conservation. Whereas the water availability sub-system will consist of four water sources available in the city of Cilegon, namely Cidanau river water which is accommodated in the Krenceng Reservoir, surface ground water, collected rainwater, and desalinated seawater. 
Cilegon City was chosen as a research location because Cilegon City met the consideration of determining the study area requirements, namely: an independent city, a coastal city that has geostrategic advantages, and has all the functions of a coastal city (settlements, urban, industrial, tourism, and conservation).

The data used from this study consists of primary data and secondary data. Primary data were obtained from sources, while secondary data were obtained from statistics released by the Central Statistics Agency of the City of Cilegon, the results of previous studies and other supporting documents.

\section{Results and Discussions}

\subsection{Cilegon City Water Resource Simulation Simulation Model}

Causal loop diagram or often called causal loop diagram (CLD) is a structure of thinking in an effort to understand complex problems through simplification steps (Muhammadi, et.al, 2001). The causal loop structure is created so that it can help understand the effect of one variable on another, with each variable identified as a specific component or factor and interacting dynamically based on time and condition.

The model is an imitation of the actual condition (Ford, 1999). The Cilegon City water resource balance model which was built into the SFD, was also built by researchers because researchers have limited thinking capacity to solve very complex problems. So the model is used to help solve the problems encountered in this study. Simply stated, the balance of water resources in the City of Cilegon, is simulated as follows.

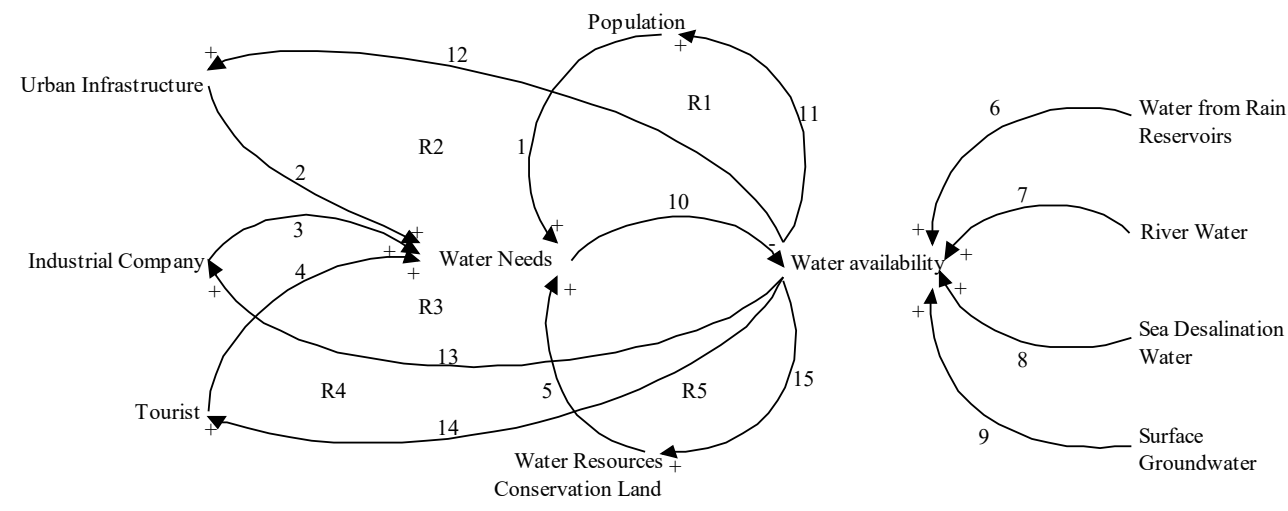

Fig. 1. Causal Loop Diagram Cilegon City Water Resources Balance

The water resource balance sheet as seen in Figure 1, that simulates a balance between the availability of water resources and water resource needs over a period of 20 years (2008-2027), arranged like a discount simulation (next to one side) shows the results of the comparison between availability (assets) and needs (liabilities) as follows. 
Table 1. Comparison between Water Needs and Water Availability in 2008-2027

\begin{tabular}{|r|r|r|}
\hline Year & Water Needs (Litre) & Water Availability (Litre) \\
\hline 2008 & - & - \\
\hline 2009 & 27.402 .057 .750 & 38.425 .016 .885 \\
\hline 2010 & 55.769 .961 .975 & 46.467 .043 .939 \\
\hline 2011 & 85.157 .229 .220 & 114.129 .923 .663 \\
\hline 2012 & 115.622 .405 .862 & 151.417 .460 .261 \\
\hline 2013 & 14.522 .969 .527 & 188.333 .420 .020 \\
\hline 2014 & 180.049 .640 .534 & 224.881 .531 .693 \\
\hline 2015 & 214.159 .973 .985 & 261.065 .486 .878 \\
\hline 2016 & 249.646 .480 .753 & 296.888 .940 .385 \\
\hline 2017 & 286.604 .057 .461 & 332.355 .510 .609 \\
\hline 2018 & 325.137 .883 .649 & 367.468 .779 .896 \\
\hline 2019 & 365.364 .758 .721 & 402.232 .294 .903 \\
\hline 2020 & 407.414 .622 .022 & 436.649 .566 .956 \\
\hline 2021 & 451.432 .281 .474 & 470.724 .072 .409 \\
\hline 2022 & 497.579 .379 .800 & 504.459 .252 .986 \\
\hline 2023 & 546.036 .631 .362 & 537.858 .516 .140 \\
\hline 2024 & 597.006 .367 .318 & 570.925 .235 .388 \\
\hline 2025 & 650.715 .432 .000 & 603.662 .750 .656 \\
\hline 2026 & 707.418 .479 .477 & 636.074 .368 .617 \\
\hline 2027 & 767.401 .726 .052 & 668.163 .363 .022 \\
\hline
\end{tabular}

To more easily understand the comparison of the two Tables, it can be seen the following Water Resources Balance Simulation Table.

Table 2. Cilegon City Water Resources Balance Year 2008-2027

\begin{tabular}{|r|r|}
\hline Year & \multicolumn{1}{|c|}{ Water Balance } \\
\hline 2008 & \\
\hline 2009 & 11.022 .959 .135 \\
\hline 2010 & $(9.302 .918 .036)$ \\
\hline 2011 & 28.972 .694 .443 \\
\hline 2012 & 35.795 .054 .399 \\
\hline 2013 & 173.810 .450 .493 \\
\hline 2014 & 44.831 .891 .159 \\
\hline 2015 & 46.905 .512 .893 \\
\hline
\end{tabular}




\begin{tabular}{|l|r|}
\hline Year & \multicolumn{1}{|c|}{ Water Balance } \\
\hline 2016 & 47.242 .459 .632 \\
\hline 2017 & 45.751 .453 .148 \\
\hline 2018 & 42.330 .896 .247 \\
\hline 2019 & 36.867 .536 .182 \\
\hline 2020 & 29.234 .944 .934 \\
\hline 2021 & 19.291 .790 .935 \\
\hline 2022 & 6.879 .873 .186 \\
\hline 2023 & $(8.178 .115 .222)$ \\
\hline 2024 & $(26.081 .131 .930)$ \\
\hline 2025 & $(47.052 .681 .344)$ \\
\hline 2026 & $(71.344 .110 .860)$ \\
\hline 2027 & $(99.238 .363 .030)$ \\
\hline
\end{tabular}

By observing Table 2, it can be seen that at the beginning of the simulation year in 2008 , the amount of water availability was still higher than the amount of water needed in the city of Cilegon. However, over time the amount of water demand in the City of Cilegon has seen a significant increase at the rate of $14 \%$ based on the Office of Investment and Integrated Services of the One Door Cilegon City (2017).

This increase in demand is unfortunately not matched by an increase in water availability in the city of Cilegon, which is actually underdeveloped, given that the flow rate of water from the Cidanau River to the Krenceng Reservoir actually shows a decrease due to changes in land use in the upstream of the River from Tangerang Regency, as well as the use of water for activities industry in several parts of the Cidanau River Basin (Krakatau Tirta Industri, 2012).

Efforts to increase clean water reserves are pursued through rainwater collection and utilization of desalination water from the sea. However, both the rate and amount of clean water generated from the two efforts was calculated by simulation, not yet significant enough to maintain the balance of water resources in the City of Cilegon.

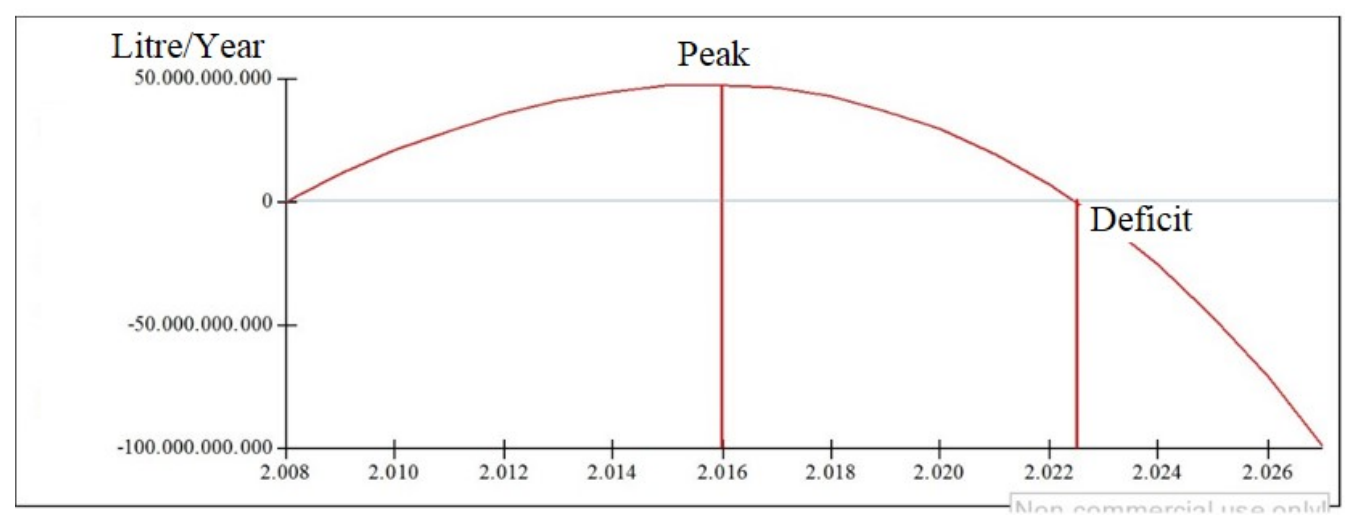

Fig. 2. Analysis of Cilegon City Water Resources Balance Year 2008-2027 
The simulation results of the Cilegon City water resources balance between 2008 and 2027 show in Figure 2, shows that in 2016 the peak year of water availability in the city of Cilegon, which was 47 billion cubic liters of water, but the following year in 2017, the availability of water began reduced and caused the graph to decline until in the 15th year from the start of the simulation or in the year 2023, the balance of water resources in the city of Cilegon entered a water deficit or crisis.

\subsection{Scenario Mitigation of Water Crisis in $\mathbf{2 0 2 5}$}

Predictions based on the results of existing conditions simulations estimate that the water crisis in Cilegon City is very likely to occur in 2023. As a result of predictions obtained based on dynamic system model simulation, efforts to mitigate clean water crises in Cilegon City should also be carried out based on scenarios to improve water resource balance simulation. So based on the same existing conditions, a future condition can be obtained with Cilegon City no longer in a water crisis condition, which is achieved through the application of scenarios based on the objectives to be achieved.

The water crisis is a phenomenon where there are less water resources available than water needs. Indonesia as a tropical country with an average of 2,000 millimeters of rainfall per year (BPS, 2018) actually has abundant water resources, with springs, rivers and lakes easily found everywhere. But in fact, since 1994, the Ministry of Public Works (now the Ministry of Public Works and Public Housing) has warned that in 2025 there will be a water crisis in Indonesia. Three years later, in 1997, BAPPENAS was reminded of the predictions of the water crisis in 2025.

Cilegon City is one of the most developed coastal cities in Indonesia due to its industry growth rate which reached $14 \%$. Based on the prediction results of the simulation model, the City of Cilegon is also not immune to the threat of the water crisis, which is even predicted to occur sooner than the Ministry of PUPR and BAPPENAS predicted. If the Ministry of PUPR and BAPPENAS predict that Regencies / Cities in Indonesia will experience a water crisis in 2025, the City of Cilegon will experience it two years earlier, namely in 2023.

Comparison of the arrival of the water crisis in 2025 according to the predictions of PUPR and BAPPENAS with the predictions of researchers in 2023, both are predictions based on an analysis of data and facts. So what then becomes important is how to reach a solution to avoid the water crisis.

The solution that is attempted to be built is to develop a theoretical solution to the problem of water crisis in 2023 in accordance with the reality of data and facts. Therefore, based on the Cilegon City water resource balance model that has been built, the researchers formulated a scenario to avoid the water crisis in 2023 by carrying out functional interventions as follows:

1) Water Needs (Passiva):

a) Pressing the population growth rate which currently reaches $2.42 \%$, exceeding the National average.

b) Pressing the rate of water use in the Settlement Function by $10 \%$, can be realized through the Water Saving Movement at the Household level.

c) Reducing water use in the Urban Function by $15 \%$, can be realized through the construction of Rainwater Storage Installations to substitute non-consumption water needs in Cilegon City Government buildings such as Government Buildings, Educational Facilities, Health Facilities, Trade Facilities, and Public Offices . The City Government of Cilegon can strengthen through a Regional Regulation that calls for this purpose. 
d) Reducing the use of water in the Industrial Function by $1 \%$, can be realized through the construction of Rainwater Reservoir Installation to substitute non-consumption water needs in Industrial Company office buildings. The City Government of Cilegon can strengthen through a Regional Regulation that calls for this purpose.

2) Water Availibility (Aktiva):

a) Integrated Cidanau watershed management through cooperation between boundaries. This collaboration seeks to improve the Cidanau watershed starting from the upstream region, so that the flow of water that flows from the upstream area of the Cidanau River in Tangerang Regency can be maintained. The Provincial Government of Banten together with the Central Government through the Cidanau River Basin Agency can issue Regional Regulations related to the prohibition of water use in the upstream area that does not have a permit, a prohibition on the conversion of land that is not in accordance with the purpose of conserving water resources, and an appeal for people living along the watershed. Cidanau to maintain the cleanliness of the Cidanau watershed.

b) Increased utilization of water resulting from seawater desalination by $100 \%$ of current capacity. This water utilization is strived to reduce the need for clean water in the Industrial Function, through the substitution of raw water with water resulting from sea desalination. The Regional Government of Cilegon City can issue a Regional Regulation that allows the private sector to carry out seawater desalination efforts to clean water for Industry. The Local Government of Cilegon City can also provide incentives to companies that have succeeded in reducing their need for raw water by substituting desalinated water.

Based on the functional intervention effort, a change in simulation results is obtained to mitigate the water crisis in 2025 which is compared as follows.

Table 3. Comparison of Existing Water Resources Balance Sheet with Water Crisis Mitigation Scenario 2025

\begin{tabular}{|r|r|r|r|}
\hline Year & Water Balance Existing & Year & Water Balance Mitigation \\
\hline 2008 & - & 2008 & - \\
\hline 2009 & 11.022 .959 .135 & 2009 & $11.022 .959 .135,00$ \\
\hline 2010 & $(9.302 .918 .036)$ & 2010 & $21.316 .360 .541,20$ \\
\hline 2011 & 28.972 .694 .443 & 2011 & $30.843 .309 .061,32$ \\
\hline 2012 & 35.795 .054 .399 & 2012 & $39.563 .222 .874,87$ \\
\hline 2013 & 173.810 .450 .493 & 2013 & $47.431 .383 .754,26$ \\
\hline 2014 & 44.831 .891 .159 & 2014 & $54.398 .429 .876,88$ \\
\hline 2015 & 46.905 .512 .893 & 2015 & $60.409 .783 .768,73$ \\
\hline 2016 & 47.242 .459 .632 & 2016 & $65.405 .006 .991,90$ \\
\hline 2017 & 45.751 .453 .148 & 2017 & $69.317 .072 .099,99$ \\
\hline 2018 & 42.330 .896 .247 & 2018 & $72.071 .541 .155,89$ \\
\hline 2019 & 36.867 .536 .182 & 2019 & $73.585 .638 .716,95$ \\
\hline 2020 & 29.234 .944 .934 & 2020 & $73.767 .205 .622,68$ \\
\hline
\end{tabular}




\begin{tabular}{|l|r|l|l|}
\hline 2021 & 19.291 .790 .935 & 2021 & $72.513 .518 .146,23$ \\
\hline 2022 & 6.879 .873 .186 & 2022 & $69.709 .955 .066,55$ \\
\hline 2023 & $(8.178 .115 .222)$ & 2023 & $65.228 .492 .953,50$ \\
\hline 2024 & $(26.081 .131 .930)$ & 2024 & $58.926 .007 .398,78$ \\
\hline 2025 & $(47.052 .681 .344)$ & 2025 & $50.642 .355 .034,37$ \\
\hline 2026 & $(71.344 .110 .860)$ & 2026 & $40.198 .207 .912,52$ \\
\hline 2027 & $(99.238 .363 .030)$ & 2027 & $27.392 .608 .129,51$ \\
\hline
\end{tabular}

By comparing the Existing Condition Table (left) with the 2025 Water Crisis Mitigation Scenario Simulation Results (right), it can be seen that there is a change, in the form of no water crisis in 2023 according to the predicted predictions or in 2025 according to the predictions of PUPR and Bappenas.

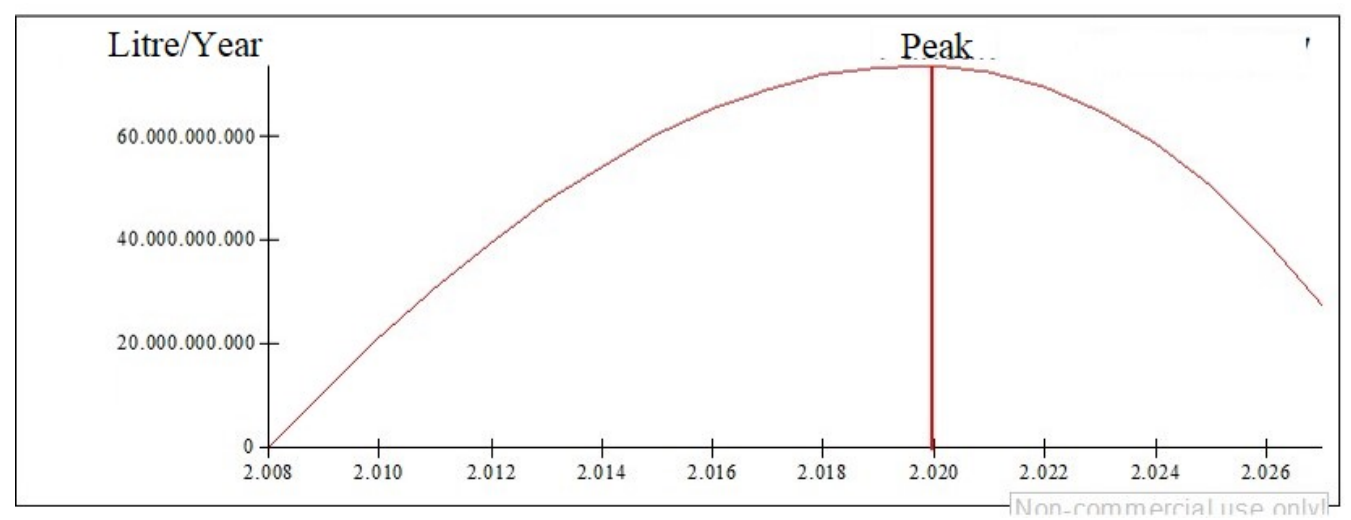

Fig. 3. Comparison of Existing Water Condition Charts with 2025 Water Crisis Mitigation Scenarios

As shown in Figure 3, it is known that the peak of water availability will occur in 2020, and although until the year 2027 there has not been a water crisis, the direction of the graph remains down which means that after 2027 the City of Cilegon can still experience a water crisis.

\section{Conclusion}

Simulation results based on existing conditions have shown that as predicted by the Ministry of PUPR and also BAPPENAS that the City of Cilegon will experience a water crisis. The simulation results even estimate that the clean water crisis in Cilegon City happened two years faster than expected, namely in 2023. By intervening functionally, it can be proven that the water crisis can be mitigated so that it does not occur until the end of 2027. But basically the level water demand in the City of Cilegon has been very high due to the need for Industrial Functions and Settlement Functions, so that being the Government of the City of Cilegon is faced with difficult challenges due to the impossibility of suppressing industrial growth rates 
that directly affect the economy of the City of Cilegon, so the realistic choice for the Government of the City of Cilegon is reduce the need for water from settlements and encourage increased availability of water sourced from the Cidanau River, Rainwater reservoirs, and utilization of seawater desalination.

\section{Acknowledgement}

This research was funded by the University of Indonesia PITMA A Grant Fund

\section{References}

[1] Badan Pusat Statistik, 2018. Jumlah Curah Hujan dan Jumlah Hari Hujan di Stasiun Pengamatan BMKG, 2011-2015.

[2] BAPPENAS, (1997). Krisis Water Bersih di Indonesia

[3] Dinas Penanaman Modal dan Pelayanan Terpadu Satu Pintu Kota Cilegon, (2017). DPMPTSP Kota Cilegon dalam Keberhasilan Pertumbuhan Investasi

[4] FAO, 2018. Water: A finite resources. Diakses dari : http://www.fao.org/docrep/u8480e/U8480E0c.htm.

[5] Ford, Andrew. (1999). Modelling the environment: an introduction to system dynamics. models of environment systems. Island Press. Washington. D.C. Covelo, California.

[6] Kabar Banten, 2019. Pertumbuhan Industri Pesat, Kota Cilegon Krisis Tambahan Water Baku.

[7] Kementerian Kelautan dan Perikanan. (2008). Pedoman kota pesisir. Direktorat Tata Ruang Laut Pesisir dan Pulau-pulau Kecil. Direktorat Jenderal Kelautan Pesisir dan Pulau-pulau Kecil.

[8] Kementerian Pekerjaan Umum dan Perumahan Rakyat (PUPR), 1995. Kebutuhan Water Masyarakat di Pulau Jawa, Bali dan Nusa Tenggara

[9] Krakatau Tirta Industri, (2012). Pengolahan Water Bersih Krakatau Tirta Industri

[10] Muhammadi, et.al, 2001. System Dynamics

[11] Pusat Riset Perkotaan dan Wilayah, (2015). Keberlanjutan kota pesisir dalam mengantisipasi perubahan iklim dan kebencanaan. Program Studi Pasca Sarjana. Universitas Indonesia.

[12] Rakhmawati, (2015). Kekeringan, Dua Desa di Cilegon Krisis Water Bersih.

[13] Suci, 2010. Permasalahan Krisis Water Di Banten.

[14] Sugiarto, (2006), Kinerja Pelayanan Water Bersih di kota Cilegon. Tesis. Universitas Dipononegoro

[15] United Nations, (1993). Resolusi Nomor 47 Tahun 1993 tentang Observance of World Day of Water (Hari Water Dunia) 